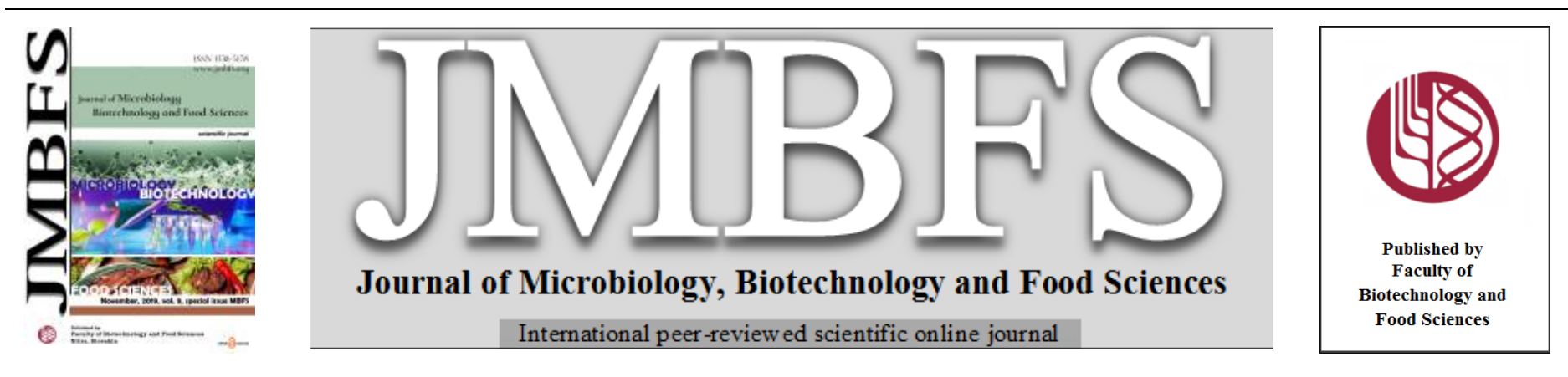

\title{
EFFECT OF PEPTIDOGLYCAN OF STAPHYLOCOCCUS AUREUS ON APOPTOSIS OF BOVINE MAMMARY GLAND LYMPHOCYTES
}

\author{
Petr Slama ${ }^{*}$, , Terezie Zavadilova ${ }^{1}$, Lucie Kratochvilova ${ }^{1}$, Kristina Kharkevich $^{1}$, Michal Uhrincat $^{2}$, Vladimir Tancin ${ }^{2,3}$ \\ Address(es): Ing. Petr Slama, Ph.D. \\ ${ }^{1}$ Mendel University, Faculty of AgriSciences, Department of Animal Morphology, Physiology and Genetics, Zemedelska 1, 61300 Brno, Czech Republic, phone \\ number: +420 545133146 . \\ ${ }^{2}$ NPPC-Research Institute for Animal Production, Hlohovecka 2, 95141 Luzianky, Slovak Republic. \\ ${ }^{3}$ Slovak University of Agriculture in Nitra, Faculty of Agrobiology and Food Resources, Department of Veterinary Sciences, Trieda A. Hlinku 2, 94976 Nitra, Slovak \\ Republic.
}

*Corresponding author: petr.slama@mendelu.cz

doi: 10.15414/jmbfs.2019.9.special.445-446

\section{ARTICLE INFO}

Received 31. 7. 2019

Revised 29. 9. 2019

Accepted 7. 10. 2019

Published 8. 11. 2019

Regular article

open $\bigodot_{\text {access }}$

\section{INTRODUCTION}

Staphylococcus aureus is one of the most important pathogen which is able to cause bovine mastitis (Petersson-Wolfe et al. 2010). These bacteria contain peptidoglycan in their cell wall. Peptidoglycan is also found in the cell wall of Gram-negative bacteria but in different structure than in Gram-positive bacteria (Vollmer et al., 2008). This natural molecule of bacteria is able to induce inflammatory response of bovine mammary gland (Furukava et al., 2018) Sulabh et al. (2019) have confirmed the stimulant effect of peptidoglycan of $S$. aureus on peripheral blood mononuclear cells obtained from blood samples of crossbred cattle, Tharparkar cattle, and Murrah buffaloes. Peptidoglycan stimulates leukocytes and also epithelial cells during mastitis (Im et al., 2014). S. aureus is also able to produce enterotoxins. These enterotoxins (staphylococcal enterotoxin C, $\alpha$-toxin) induce activation and apoptosis of T cells (Damle et al., 1993; Webb and Gascoigne, 1994; Boshell et al., 1996) and apoptosis of peripheral blood mononuclear cells (Haslinger et al., 2003).

In context of previous information, changes of programmed cell death can be caused by different inducers in frame work of bacteria - by components of cell wall or product of bacteria mainly toxins. We previously studied the effect of $S$. aureus and Streptococcus uberis on lymphocyte apoptosis of bovine mammary gland (Slama et al., 2009a). We have found that apoptosis of lymphocytes was delayed by those bacterial species during experimental infection and in in vitro study, too. Therefore, we would like to know whether peptidoglycan as the molecule naturally found in the cell wall of $S$. aureus can also modulate lymphocyte apoptosis in the same manner or in different way.

The aim of this study was to determine whether apoptosis of bovine mammary gland lymphocytes is modulated during an inflammatory response of bovine mammary gland induced by peptidoglycan.

\section{MATERIAL AND METHODS}

For our experiments, we used eight clinically healthy virgin heifers (Holstein $x$ Bohemian Red Pied crossbred) in age 16 to 18 months. All animals were free of infection of the mammary glands. Bacteriological examination of mammary gland lavages was executed by culturing on blood agar with aerobic incubation at $37^{\circ} \mathrm{C}$ for 24 hours.

For the experimental infection, there were used urethral catheter (AC5306CH06, Porges SA, France) to insert into the teat canal after disinfection of the teat orifice (Sladek et al., 2005; Slama et al., 2009a). Each mammary gland in each quarter of the udder was injected with $20 \mathrm{ml}$ phosphate buffered saline (PBS) with $50 \mu \mathrm{g}$ of peptidoglycan of $S$. aureus (Sigma, USA). Before experimental infection, the mammary glands were used for preparation of control samples through treatment by PBS as previously described (Sladek et al., 2005).

The lymphocytes obtained by lavages of mammary glands were analysed by flow cytometry (FACS Calibur Apparatus, Becton Dickinson, CA, USA) and subsequently by software WinMDI 2.8 (Trotter, 2000) as in previous studies (for example Slama et al., 2006). Proportion of apoptotic lymphocytes was enumerated by staining with Annexin-V (FITC) and propidium iodide (PE) previously described by Vermes et al. (1995).

For statistical analysis, there were used statistical software STATISTICA 8.0 (StatSoft, Czech Republic). Arithmetic means and standard deviations were used to describe apoptosis of lymphocytes. Statistically significant differences in the proportion of apoptotic lymphocytes were determined by paired $t$-test.

\section{RESULTS AND DISCUSSION}

The aim of this study was to evaluate the effect of peptidoglycan on apoptosis of bovine mammary gland lymphocyte during experimentally induced inflammation.

In this study, the apoptosis of lymphocytes was changed during the inflammatory response. Experimental infusion of peptidoglycan into the mammary gland led to increase of lymphocyte apoptosis with the maximum in 48 hours following stimulation of the mammary glands compare to the control (Figure 1). 


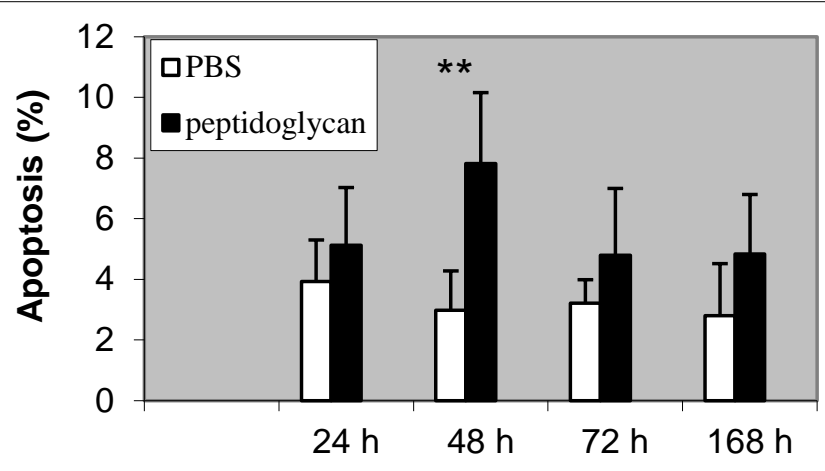

Figure 1 Apoptosis of mammary gland lymphocytes $(\%)$ following stimulation by peptidoglycan in four timepoints $(24,48,72,168$ hours). PBS - phosphate buffered saline; $* * \mathrm{P}<0.01$

These results suggest that peptidoglycan can induce apoptosis of lymphocytes. Contrary to that, our previous results shown that $S$. aureus or $S$. uberis can delay apoptosis of lymphocytes (Slama et al., 2009a). Slight increase in apoptosis of T lymphocytes was detected by Park et al. (2006). Those authors cultivated lymphocytes with staphylococcal enterotoxin $\mathrm{C}$ in vitro. Those mentioned information suggest that components of bacterial cell wall could be more effective in induction of lymphocyte apoptosis in the initial stage of inflammation. Later, bacteria produce toxins which can be effective apoptotic inducer but in the late stage of inflammation. Apoptosis of cells is very important to protect mammary gland tissue damage during mastitis. Apoptotic cells have stable cell membrane and the content of the cell is not spread into surrounding tissue. On the other hand, necrosis of cells is dangerous to tissue because the cell membrane of these cells is damaged. If the necrotic cells are neutrophils, they can harm the mammary tissue by releasing reactive oxygen intermediates and proteolytic enzymes (Zhao and Lacasse, 2008)

In our study, we used peptidoglycan of $S$. aureus as Gram-positive bacteria Question remains, if Gram-negative bacteria or the components of their cell wall are able to affect the lymphocyte apoptosis in the same way. Our preliminary results (unpublished data) indicate that lipopolysaccharide of Escherichia coli has similar effect on apoptosis of lymphocyte in vivo. Yokochi et al. (1996) also shown that lipopolysaccharide induced apoptosis of B lymphocytes. In contrary to that, we reported that lipopolysaccharide can delay apoptois of lymphocytes in in vitro conditions (Slama et al., 2009b). We also used muramyl dipeptide to stimulate lymphocytes in vitro. Muramyl dipeptide is the minimal structural unit of peptidoglycan. We found out that apoptosis of lymphocytes was also delayed using muramyl dipeptide (Slama et al., 2009c). Contrast in results of in vitro and in vivo studies can be possible. In vitro study only says what cells are able to do but in in vivo conditions there are more variables which can play important role in final results of experiments. Moreover, there are produced different cytokine during mastitis by immune cells. These cytokines are able to modulate apoptosis of cells. In the initial stage of mastitis, there is produced tumor necrosis factor alpha by neutrophils (Sohn et al., 2007). That cytokine is able to induce apoptosis of cells (Rath and Aggarwal, 1999) and therefore the highest percentage of lymphocyte apoptosis is found out in 48 hours following the start of inflammation.

\section{CONCLUSION}

The results suggest that the cell wall components as peptidoglycan are able to modulate lymphocyte apoptosis during the process of inflammation of the mammary gland. We studied whole population of lymphocytes and therefor it is necessary to continue to investigate different subpopulation of lymphocytes. Different subpopulation of lymphocytes could have different resistance to bacterial compounds and toxins.

Acknowledgments: The authors wish to express their thanks for financial support to the projects of IGA AF MENDELU No. AF-IGA-2018-tym002 and the Ministry of Education Science Research and Sports of the Slovak Republic/the Slovak Research and Development Agency (Project No. APVV-150072)

\section{REFERENCES}

BOSHELL, M., MCLEOD, J., WALKER, L., GALL, N., PATEL, Y., SANSOM, D. 1996. Effects of antigen presentation on superantigen-induced apoptosis mediated by Fas/Fas ligand interactions in human T cells. Immunology, 87, 586592.

DAMLE, N.K., LEYTZE, G., KLUSSMAN, K., LEDBETTER, J.A. 1993. Activation with superantigens induced programmed cell death in antigen primed $\mathrm{CD}^{+}$class $\mathrm{II}^{+}$major histocompatibility complex $\mathrm{T}$ lymphocytes via a
CD11a/CD18-dependent mechanism. European Journal of Immunology, 23 1513-1522.

FURUKAVA, M., YONEYAMA, H., HATA, E., IWANO, H., HIGUCHI, H. ANDO, T., SATO, M., HAYASHI, T., KIKU, Y., NAGASAWA Y., NIIMI, K. USAMI, K., ITO, K., WATANABE, K., NOCHI, K., ASO, H. 2018 Identification of a novel mechanism of action of bovine $\mathrm{IgG}$ antibodies specific for Staphylococcus aureus. Veterinary Research, 49, 22. http://dx.doi.org/10.1186/s13567-018-0517-y

HASLINGER, B., STRANGFELD, K., PETERS, G., SCHULZE-OSTHOFF, K. SINHA, B. 2003. Staphylococcus aureus $\alpha$-toxin induces apoptosis in peripheral blood mononuclear cells: role of endogenous tumour necrosis factor- $\alpha$ and the mitochondrial death pathway. Cellular Microbiology, 5, 729-741.

IM, J., LEE, T., JEON, J.H., BAIK, J.E., KIM, K.W., KANG, S.S., YUN, C.H KIM, H., HAN, S.H. 2014 Gene expression profiling of bovine mammary gland epithelial cells stimulated with lipoteichoic acid plus peptidoglycan from Staphylococcus aureus. International Immunopharmacology, 21, 231-240. http://dx.doi.org/10.1016/j.intimp.2014.05.002

PARK, Y.H., LEE, S.U., FERENS, W.A., SAMUELS, S., DAVIS, W.C., FOX L.K., AHN, J.S., SEO, K.S., CHANG, B.S., HWANG, S.Y., BOHACH, G.A 2006. Unique features of bovine lymphocytes exposed to a staphylococcal enterotoxin. Journal of Veterianry Science, 7, 233-239. http://dx.doi.org/10.4142/jvs.2006.7.3.233

PETERSSON-WOLFE, C.S., MULLARKY, I.K., JONES, G.M. 2010 Staphylococcus aureus mastitis: cause, detection, and control. Virginia Cooperative Extension, 404-229.

RATH, P.C., AGGARWAL, B.B. 1999. TNF-induced signaling in apoptosis Journal of Clinical Immunology, 19, 350-364.

SLADEK, Z., RYSANEK, D. RYZNAROVA, H., FALDYNA, M. 2005 Neutrophil apoptosis during experimentally induced Staphylococcus aureus mastitis. Veterinary Research, 36, 243-262. http://dx.doi.org/10.1051/vetres:2005023

SLAMA, P., SLADEK, Z., RYSANEK, D. 2006. Effect of isolation techniques on viability of bovine blood neutrophils. Acta Veterinaria Brno, 75, 343-353. http://dx.doi.org/10.2754/avb200675030343

SLAMA, P., SLADEK, Z., RYSANEK, D., LANGROVA, T. 2009a. Effect of Staphylococcus aureus and Streptococcus uberis on apoptosis of bovine mammary gland lymphocytes. Research in Veterinary Sciences, 87, 233-238. http://dx.doi.org/10.1016/j.rvsc.2009.03.005

SLAMA, P., SLADEK, Z., RYSANEK, D. 2009b. Lipopolysaccharide delays apoptosis of bovine lymphocytes. FEBS Journal, 276, 223.

SLAMA, P., SLADEK, Z., RYSANEK, D. 2009c. Effect of muramyl dipeptide on apoptosis of bovine mammary gland lymphocytes in vitro. Slovak Journal of Animal Science, 42, 90-93.

SOHN, E.J., PAAPE, M.J., CONNOR, E.E., BANNERMAN, D.D., FETTERER, R.H., PETERS, R.R. 2007. Bacterial lipopolysaccharide stimulates bovine neutrophil production of TNF-alpha, IL-1beta, IL-12 and IFN-gamma. Veterinary Research, 38,809-818. http://dx.doi.org/10.1051/vetres:2007033

SULABH, S., PANIGRAHI, M., AHMAD, S.F., VARSHNEY, R., VERMA, A., BABA, N.A., KUMAR, S., KUMARI, S., CHAUHAN, A., KUMAR, P. BHUSHAN, B. 2019. Peptidoglycan and Lipoteichoic Acid Induces Differential mRNA Response of Immune-Related Genes in PBMC of Crossbred, Tharparkar Cattle and Murrah Buffalo. Animal Biotechnology, 30, 166-174. http://dx.doi.org/10.1080/10495398.2018.1461633

TROTTER, J.: WinMDI Version 2.8. 2000. http://facs.scripps.edu/

VERMES, I, HAANEN, C., STEFFENS-NAKKEN, H, REUTELINGSPERGER, C. 1995. A novel assay for apoptosis. Flow cytometric detection of phosphatidylserine expression on early apoptotic cells using fluorescein labelled Annexin V. Journal of Immunological Methods, 184, 39-51. VOLLMER, W., BLANOT, D., DE PEDRO, M.A. 2008. Peptidoglycan structure and architecture. FEMS Microbiology Reviews, 32, 149-167. http://dx.doi.org/10.1111/j.1574-6976.2007.00094.x

WEBB, S.R., GASCOIGNE, N.R. 1994. T-cell activation by superantigens. Current Opinion in Immunology, 6, 467-475.

YOKOCHI, T., KATO, Y., SUGIYAMA, T., KOIDE, N., MORIKAWA, A. JIANG, G.Z. KAWAI, M., YOSHIDA, T., FUKADA, M., TAKAHASHI, K 1996. Lipopolysaccharide induces apoptotic cell death of B memory cells and regulates $\mathrm{B}$ cells in antigen non-specific manner. FEMS Immunology and Medical Microbiology, 15, 1-8.

ZHAO, X., LACASSE, P. 2008. Mammary tissue damage during bovine mastitis: causes and control. Journal of Animal Science, 86, 57-65. http://dx.doi.org/10.2527/jas.2007-0302 